\title{
PENGARUH PENGGANTIAN KATETER INTRAVENA DAN SET INFUS TERHADAP TERJADINYA PHLEBITIS
}

\author{
Ni Luh Widani \\ Program Studi Ilmu Keperawatan \\ Sekolah Tinggi Ilmu Kesehatan Sint Carolus Jakarta, 10440, Indonesia \\ E-mail:widani24@gmail.com
}

Diterima: November 2017, diterbitkan: April 2018

\begin{abstract}
ABSTRAK
Pemasangan infus adalah prosedur umum pada pasien di rumah sakit dimana komplikasi yang umum terjadi adalah phlebitis. Tujuan penelitian: menganalisis pengaruh penggantian kateter intravena (iv) dan set infus terhadap kejadian phlebitis. Metode: penelitian kuantitatif, desain Kohort, sampel sebanyak 247 diambil secara purposif, pasien dewasa yang terpasang infus perifer dirawat di RS Sint Carolus Jakarta pada Bulan November 2016.. Dilakukan pengamatan tusukan infus sejak pemasangan sampai pencabutan oleh peneliti dan dua orang asisten. Data dikumpulkan dengan melihat rekam medis untuk melihat karakteristik pasien dan lembar observasi dan VIP score (Visual infusion phlebitis score). Uji statistik yang digunakan adalah kendall-tau- $C$ dan kendall-tau- $B$ dengan tingkat kemaknaan $\mathrm{p}<0,05$. Hasil: Kejadian phelebitis $5,3 \%$. Analisis bivariate Kendal's tau $C$ menunjukkanada hubungan pemberian terapi iv bolus $(\mathrm{p}=0,03)$, lama pemasangan kateter iv $(\mathrm{p}=0,00)$ terhadap terjadinya phlebitis $(\mathrm{p}<0,05)$. Uji regresi logistik didapatkan variabel independen memberikan kontribusi kejadian phlebitis sebesar $24,5 \%$. Uji probabilitas disimpulkan responden yang tidak diganti tusukan infus rutin dan set drip secara rutin berisiko phlebitis sebesar 100\%. Diskusi: Hasil penelitian ini menyimpulkan pentingnya penggantian kateter intravena perifer dan penggantian set infus untuk pemberian terapi drip secara rutin untuk mencegah terjadinya phlebitis. Kesimpulan: penelitian lebih lanjut menganalisis faktor risiko phlebitis di luar faktor yang telah diteliti seperti faktor tetesan dan ketrampilan perawat dalam pemasangan infus.
\end{abstract}

Kata kunci: Kateter Intravena, phlebitis, set infus

\section{EFFECTOFREPLACEMENT OF INTRAVENOUS CATHETERAND INFUSION SET ON PHLEBITIS ABSTRACT}

Infusion is a common procedure in patients in hospitals in which the most common complication is phlebitis. Objective: To analyze the effect of the replacement of intravenous catheter (iv) and infusion set on the incidence of phlebitis. Methods: This research is quantitative with cohort design. 247 samples were taken purposively, consisting of adult patients receiving peripheral infusions treated at Saint Carolus Hospital of Jakarta in November 2016. The researcher and two assistants observed infusion punctures from insertion until extraction. Data were collected by reading medical records to see patient characteristics and observation sheets and VIP (Visual infusion phlebitis) score. The statistical test used Kendall'tau-C and Kendall's tau-B with a significance level of $p<0.05$. Results: the incidence of phlebitis was $5.3 \%$. The results of bivariate analysis using Kendal's tau- $C$ showed that there was a correlation between iv bolus therapy ( $p=0.03)$, iv catheter insertion time ( $(=0.00)$ to incidence of phlebitis $(p<0.05)$. The logistic regression test found that the independent variables contributed to the incidence of phlebitis by $24.5 \%$. the probability test concluded that respondents whose infusion puncture and set drip were not regularly replaced had a risk of phlebitis by $100 \%$. Discussion: The results of this research concluded the importance of replacing peripheral intravenous catheter and replacing infusion sets for drip therapy regularly in order to prevent phlebitis. Conclusion: Further research is recommended to analyze the risk factors for phlebitis beyond the factors that have been investigated such as droplet factors and nurses'skills in infusion insertion.

Keywords: Intravenous catheter, phlebitis, infusion set 


\section{LATAR BELAKANG}

Pasien yang dirawat di rumah sakit (RS) sering mendapat terapi penggantian cairan atau obat-obatan melalui keteter intravena (iv). Lebih dari $80 \%$ pasien mendapatkan terapi melalui intravena dengan melakukan pemasangan kateter intravena (Çakar, 2008). Kateter iv perifer berukuran pendek ditempatkan di pembuluh darah vena perifer untuk mengalirkan obat-obatan, cairan atau nutrisi langsung ke pembuluh darah. Pemberian terapi ini membutuhkan set infus sebagai penghubung antara kateter dan cairan infus (Webster et al., 2015). Pemberian terapi iv dapat menimbulkan beberapa komplikasi serius antara lain ekstravasasi, eccymosis, hematoma, infeksi dan phlebitis (Uzun, 2012).

Phlebitis akibat pemasangan kateter perifer adalah peradangan dari tunika intima dari vena superfisial. Peradangan terjadi akibat iritasi dari intima tunika oleh mekanik, kimia atau bakteri (Royal College of Nursing/ RCN, 2010). Phlebitis didiagnosis dengan satu atau lebih tanda dan gejala dari nyeri, tegang, bengkak, indurasi, dan kemerahan (Ray-Barruel et al., 2014). Angka kejadian phlebitis $52,2 \%$ dari 224 sample pasien yang terpasang infus di salah satu RS di Afrika (Osei-Tutu et al., 2015).

Insiden phlebitis dari penelitian Pasalioglu \& Kaya (2014) terhadap 439 pasien terpasang infus didapatkan sebanyak 111 responden $(59,7 \%)$ terjadi pada 48 jam setelah pemasangan kateter iv, sebanyak 52 responden $(37,1 \%)$ terjadi pada 49-96 jam setelah pemasangan dan 18 responden $(15,9 \%)$ pada pemasangan 97-120 jam. Penelitian oleh Triyanto \& Upoyo (2006) terhadap 74 responden di RSUD Purbalingga kejadian phlebitis sebanyak $22,9 \%$.

Kejadian phlebitis dapat terjadi selama pemasangan iv dan dapat juga terjadi setelah kateter iv dilepas. Studi RCT (Randomized
Control Trial) oleh Webster, et al. (2015) di klinik di RS di Australia terhadap 3.283 pasien yang terpasang infus, didapatkan kejadian phlebitis dalam 48 jam setelah pelepasan infus ditemukan sebanyak 59 $(1,8 \%)$ pasien. Peneliti menyimpulkan ada hubungan antara phlebitis post pemasangan infus di unit emergency $(p=0,03)$. Penelitian lainnya oleh Cicolini et al. (2014) terhadap 1.498 responden dari $5 \mathrm{RS}$ di Italia didapatkan kejadian phlebitis sebanyak $15,4 \%$ dan mayoritas $(94,4 \%)$ adalah phlebitis grade satu. Ketiga penelitian tersebut menunjukkan angka kejadian phlebitis di atas rekomendasi dari INS (Infusion Nursing Society, 2011) yaitu sebesar $5 \%$.

Faktor yang berhubungan dengan terjadinya phlebitis antara lain: (1) faktor kimia, akibat iritasi obat atau cairan infus; (2) faktor mekanik, ukuran, lokasi dan bahan kateter iv dan keahlian saat penusukan; (3) faktor infeksi, terkontaminasi mikroorganisme dari kulit, dan kontaminasi hub dan kateter; (4) faktor pasien, adanya infeksi di tempat lain, usia, jenis kelamin (Wallis et al., 2014). Penelitian yang dilakukan oleh Triyanto \& Upoyo (2006) terhadap 74 pasien di RSUD Purbalingga, faktor risiko terjadinya phlebitis adalah ukuran kateter no $18(p=0,01)$, lama pemasangan 120 jam dan 144 jam $(p=0,01)$, tempat insersi vena fossa kubiti dan vena di kaki $(p=0,03)$, cairan hipertonis $(p=0,01)$, obat parenteral $\mathrm{pH}$ asam $(p=0,02)$ dan perawatan terapi iv setiap 72 jam $(p=0,03)$.

Dampak terjadinya phlebitis mengakibatkan memperpanjang hari rawat pasien di RS, meningkatkan biaya perawatan dan beberapa kasus dapat menimbulkan bakterimia atau pembentukan trombus (Stuart, Cameron, \& Scott, 2013).

Prosedur pencegahan terjadinya phlebitis menjadi hal yang penting untuk diketahui dan dilakukan dalam merawat pasien yang 
menggunakan terapi iv infus. Beberapa hasil penelitian membuktikan lamanya penempatan kateter iv secara signifikan berisiko terjadi phlebitis. Penelitian yang dilakukan oleh Osei-Tutu et al. (2015) terhadap 224 pasien yang terpasang infus di unit medikal bedah, diadapatkan kejadian phlebitis lebih tinggi di antara pasien yang terpasang kateter iv lebih dari hari keempat (66,3\%) dibandingkan dengan pasien yang terpasang hingga hari keempat $(44,4 \%)(p=0,002)$. Penggunaan kateter iv lebih dari 4 hari berisiko empat kali lebih tinggi menyebabkan phlebitis. Peneliti menyimpulkan kejadian phlebitis secara signifikan meningkat pada hari keempat pasca-penusukan kateter iv.

Penggantian kateter IV direkomendasikan oleh Centerbury District Health Board (CDHB) (2015) adalah setiap 3-4 hari untuk mencegah iritasi pada vena atau infeksi darah dan phlebitis. Akan tetapi prosedur tersebut dapat menyebabkan ketidaknyamanan pada pasien dan biaya meningkat. Rekomendasi yang dikeluarkan oleh US Centers for Disease Control and Prevention (CDC) tidak perlu mengganti tusukan kateter intravena dewasa setiap 72-96 jam untuk mencegah phlebitis. Kateter iv diganti hanya kalau perlu, sedangkan set infus diganti setiap 3-4 hari, dipercaya mengurangi komplikasi infeksi (Webster et al., 2015).

Bolton (2015) melakukan penelitian terhadap 362 pasien yang dilakukan pemasangan infus, 185 sampel dilakukan penggantian tusukan infus bila ada kriteria dan 177 pasien dilakukan penggantian tusukan infus tiap 3 hari. Dilakukan penilaian komplikasi phlebitis, infiltrasi, sumbatan, terlepas, infeksi lokal dan infeksi darah akibat pemasangan kateter iv. Hasil penelitian didapatkan komplikasi pemasangan iv $68 / 1000$ hari (kelompok indikasi klinik) dan $66 / 1000$ hari (kelompok penggantian rutin $(p=0,86 ; \mathrm{HR} 1,03 ; 95 \% \mathrm{Cl}, 0,74-1,43)$. Tidak ada infeksi lokal atau infeksi darah terkait penusukan kateter iv pada kedua kelompok. Peneliti menyimpulkan penggantian tusukan infus pada indikasi klinis dilakukan pada satu dari dua pasien dan membutuhkan cukup satu saja kateter kanul dalam terapi iv, sebaliknya satu dari lima pasien menggunakan satu kateter kanul pada penggantian rutin. Peneliti menyimpulkan penggantian berdasarkan indikasi klinik dapat menghemat peralatan, waktu, staf dan ketidaknyamanan pasien.

Penusukan kateter iv menimbulkan rasa tidak nyaman dan menyebabkan kecemasan serta stres pada pasien. Disamping itu dapat menyebabkan infeksi, phlebitis dan infiltrasi. Di UK penusukan diganti tiap 72-96 jam sesuai dengan national guidelines (Department of Health (DH), 2007 dalam Bolton, 2015). Tiga tahun kemudian dilakukan update guideline dan rekomendasinya adalah penggantian tusukan bila ada indikasi dari pada rutin. Perubahan rekomendasi ini dalam 6 bulan terakhir didapatkan tidak ada pengaruh pada pasien. Perubahan ini telah memberikan pengaruh yang signifikan mengurangi biaya dan waktu. Diperkirakan dapat menghemat waktu 11.750 jam pada petugas yang sibuk. Hal yang paling penting bagi pasien adalah dia tidak harus menahan nyeri untuk tindakan yang tidak penting dan risiko terjadi infeksi akibat pengulangan penusukan bila tidak ada indikasi untuk tidak dilakukan (Bolton, 2015).

US Centers for Disease Control Guidelines (CDC) merekomendasikan penggantian tusukan kateter iv perifer tidak perlu rutin, dapat lebih dari 72-96 jam (3-4 hari). Webster et al. (2015) dalam studi RCT dengan membandingkan penggantian rutin kateter perifer iv dengan penggantian hanya bila ada indikasi klinik pasien di RS yang dilakukan pemasangan infus secara kontinyu terhadap tujuh penelitian dengan total sampel 4.895 pasien didapatkan tidak ada hubungan yang bermakna penggantian 
secara rutin dengan penggantian sesuai dengan indikasi klinik terhadap terjadinya infeksi Catheter-related bloodstream infection (CRBSI) dengan $p=0,64(>0,05)$ dan juga tidak ada hubungan yang signifikan kejadian phlebitis dengan $p=0,75)$. Peneliti menyimpulkan penggantian rutin ternyata tidak mengurangi risiko phlebitis dan infeksi bloodstream. Penggantian tusukan secara rutin tidak penting bila fungsi kateter baik dan tidak ada tanda dan gejala infeksi. Biaya yang dikeluarkan untuk menggantian tusukan juga dapat dihemat. Peneliti juga menyimpulkan tidak ada fakta penggantian tusukan infus tiap 72-96 jam lebih bermakna dalam pencegahan phlebitis. Penggantian kateter hanya bila ada indikasi klinik dapat menghemat biaya, waktu dan staf.

Sejalan dengan penelitian yang dilakukan oleh Pasalioglu \& Kaya (2014) di RS di Turki dari 439 pasien yang terpasang infus, 103 responden yang memenuhi kriteria, yang menyimpulkan bahwa kateter iv dapat digunakan dalam jangka waktu lama bila prosedur pemasangan dan perawatan dilakukan secara optimal dan pengkajian terjadinya phlebitis dilakukan.

Berdasarkan pengamatan dan wawancara dengan perawat di RS Sint Carolus terkait dengan praktik penggantian tusukan infus dan penggantian set infus yaitu tidak semua perawat di unit perawatan medikal bedah menerapkan praktik yang sama dalam penggantian tusukan dan penggantian set infus. Diperlukan penelitian berapa lama waktu penempatan kateter iv dan penggantian set infus yang optimal dapat mencegah phlebitis. Penelitian ini ingin mengetahui lamanya penggunaan kateter iv dan set infus yang dapat mencegah phlebitis. Apabila penggantian kateter iv setiap 3-4 hari dan penggantian set infus setiap saat pemberian terapi antibiotika drip maka meningkatkan biaya perawatan, meningkatkan beban kerja perawat, meningkatkan limbah rumah sakit dan ketidaknyamanan pasien.

Tujuan penelitian ini adalah untuk menganalisis pengaruh penggantian rutin tusukan kateter iv perifer dan penggantian rutin set infus terhadap terjadinya phlebitis di RS Sint Carolus Jakarta.

\section{METODE PENELITIAN}

Penelitian ini adalah penelitian kuantitatif dengan desain prospective cohort, yang bertujuan untuk menganalisis pengaruh penggantian rutin penusukan dan penggantian set infus drip terhadap kejadian phlebitis. Populasi penelitian ini adalah pasien yang dirawat di unit medikal dan bedah di RS Sint Carolus. Sampel dalam penelitian sebanyak 247 responden, yang dipilih secara purposive sampling, berdasarkan kriteria inklusi: 1) berusia lebih dari 15 tahun; 2) terpasang kateter iv dan terpasang infus dihubungkan dengan set infus; 3) pemberian terapi infus minimal 3 hari; sedangkan kriteria eksklusinya adalah 1) pemasangan infus untuk pemberian kemoterapi 2) pasien mengalami infeksi kulit sekitar lokasi pemasangan infus sejak sebelum pemasangan infus.

Lokasi penelitian ini dilakukan di delapan unit perawatan dewasa RS Sint Carolus Jakarta pada Bulan September 2016. Pengambilan data dilakukan setelah mendapat persetujuan dari bagian penelitian STIK Sint Carolus dan persetujuan dari RS Sint Carolus. Tehnik pengumpulan data dalam penelitian ini adalah menggunakan rekam medis pasien untuk melihat karakteristik responden (usia, jenis kelamin, terapi yang didapat, jenis infus, ukuran kateter iv) dan lembar observasi harian. Pasien diobservasi sejak hari pertama pemasangan infus sampai dengan hari ketujuh atau sampai dengan pelepasan dengan alasan tidak menggunakan terapi cairan infus. Observasi tusukan infus dilakukan setiap hari sekali 
dengan mengkaji keluhan nyeri, adanya kemerahan dan palpasi adanya bengkak pada penusukan kateter iv terhadap kejadian phlebitis. Kejadian phlebitis ditegakkan bila ditemukan dua atau lebih gejala, yaitu skala 2 atau lebih. Observasi phlebitis menggunakan Visual Infusion Phlebitis Score (VIP score) dari Jackson (1998).

RCN (2016) merekomendasikan VIP score sebagai alat atau indikator yang valid, reliabel dan secara klinis layak digunakan untuk menentukan indikasi dini plebitis dan menentukan skor yang tepat untuk plebitis. VIP score sudah diterima sebagai standar internasional, sudah digunakan di banyak negara. INS (2016) menyatakan profesi kesehatan, khususnya perawat harus kompeten dalam mengkaji tusukan infus dan menentukan tindakan selanjutnya terhadap ada atau tidaknya phelebitis. Penusukan kateter IV harus dikaji setiap shift dengan menggunakan skala VIP yang sudah diakui (Loveday et al., 2014).

VIP score yang dikembangkan oleh Andrew Jackson dibuktikan oleh Bonnici (2012) dengan melakukan penelitian di Rumah Sakit Dei Mater Imsida Malta terhadap 285 sampel. Dari hasil penelitiannya tingkat plebitis turun dari 22,7\% pada pre intervensi menjadi $6,5 \%$ pada post intervensi penerapan VIP Score. Peneliti menyimpulkan VIP Score dapat digunakan untuk mendeteksi dini terjadinya phlebitis dan penentuan yang tepat untuk skor plebitis, melalui pengamatan visual yang dilakukan oleh perawat. Phelebitis didiagnosis bila ada dua atau lebih dari gejala nyeri, bengkak, kemerahan/hangat atau indurai sekitar lokasi penusukan (RCN, 2016).

Tehnik analisis data menggunakan analisis univariat untuk menjelaskan atau mendeskripsikan karakteristik responden dan analisis bivariat bertujuan untuk menganalisis hubungan karakteristik responden dengan kejadian phlebitis. Uji statistik yang digunakan adalah kendall-tau-C dan kendalltau- $B$ dengan tingkat kemaknaan $p<0.05$ dan analisis multivariate untuk menganalisa pengaruh penggantian rutin kateter iv dan set infus terhadap kejadian phlebitis.

\section{HASIL}

Jumlah responden yang dapat dikumpulkan sejumlah 247 orang. Pada hasil univariat didapatkan bahwa sebagian besar usia responden $\geq 48$ tahun, berjenis kelamin perempuan, terapi iv bolus satu jenis, tidak mendapat terapi drip, penggantian tusukan infus pada hari ke-3 dan pada pengantian set drip sebagian besar diganti setiap pemberian (tabel 1). Sedangkan skala phlebitis sebagian besar adalah skala 2 (tabel 2). Kejadian phlebitis (skala 2 dan 3) sebanyak 13 responden (5,3\%). Hasil analisis bivariate Kendal's tau C didapatkan secara statistik ada hubungan bermakna antara jenis kelamin, pemberian terapi iv bolus, lama pemasangan, penggantian tusukan infus $(p<0.05)$, dan tidak ada hubungan antara usia, pemberian terapi drip dan penggantian set drip dengan kejadian phlebitis $(p>0,05)$ (tabel 1$)$. 
Tabel 1. Distribusi dan Analisis Hubungan Antara Karakteritik Responden dengan Kejadian Phlebitis

\begin{tabular}{|c|c|c|c|c|c|c|}
\hline \multirow{3}{*}{ Karakteristik } & \multicolumn{4}{|c|}{ Skala Plebitis } & \multirow{3}{*}{ Total } & \multirow{3}{*}{$p$ value } \\
\hline & \multicolumn{2}{|c|}{ Tidak Phlebitis } & \multicolumn{2}{|c|}{ Phlebitis } & & \\
\hline & 0 & 1 & 2 & 3 & & \\
\hline \multicolumn{7}{|l|}{ Usia } \\
\hline$<48$ tahun & 94 & 16 & 4 & 1 & 115 & \\
\hline$\geq 48$ tahun & 109 & 15 & 8 & 0 & 132 & 0,9 \\
\hline Total & 203 & 31 & 12 & 1 & 247 & \\
\hline \multicolumn{7}{|l|}{ Jenis kelamin } \\
\hline Laki-laki & 94 & 7 & 5 & 1 & 107 & 0,05 \\
\hline Perempuan & 109 & 24 & 7 & 0 & 140 & \\
\hline Total & 203 & 31 & 12 & 1 & 247 & \\
\hline \multicolumn{7}{|l|}{ Terapi iv bolus } \\
\hline Tidak dapat & 72 & 6 & 0 & 0 & 78 & 0,03 \\
\hline Satu jenis & 59 & 10 & 7 & 0 & 89 & \\
\hline$>2$ jenis & 0 & 15 & 5 & 1 & 80 & \\
\hline Total & 203 & 31 & 12 & 1 & 247 & \\
\hline \multicolumn{7}{|l|}{ Terapi drip } \\
\hline Tidak dapat & 123 & 12 & 7 & 0 & 142 & 0,08 \\
\hline Dapat & 80 & 19 & 5 & 1 & 105 & \\
\hline Total & 203 & 31 & 12 & 1 & 247 & \\
\hline \multicolumn{7}{|l|}{ Lama pemasangan } \\
\hline 3 hari & 44 & 0 & 0 & 0 & 44 & 0,00 \\
\hline 4 hari & 54 & 6 & 2 & 1 & 63 & \\
\hline 5 hari & 45 & 4 & 3 & 0 & 52 & \\
\hline 6 hari & 22 & 7 & 1 & 0 & 30 & \\
\hline 7 hari & 38 & 14 & 6 & 0 & 58 & \\
\hline Total & 203 & 31 & 12 & 1 & 247 & \\
\hline \multicolumn{7}{|l|}{ Penggantian tusukan } \\
\hline Tidak diganti & 164 & 3 & 2 & 0 & 169 & 0,00 \\
\hline Hari ke-1 & 0 & 1 & 0 & 0 & 1 & \\
\hline Hari ke-2 & 7 & 7 & 0 & 0 & 14 & \\
\hline Hari ke-3 & 8 & 11 & 8 & 1 & 28 & \\
\hline Hari ke-4 & 7 & 6 & 2 & 0 & 15 & \\
\hline Hari ke-5 & 15 & 3 & 0 & 0 & 18 & \\
\hline Hari ke-6 & 2 & 0 & 0 & 0 & 2 & \\
\hline Total & 203 & 31 & 12 & 1 & 247 & \\
\hline \multicolumn{7}{|l|}{ Set drip } \\
\hline Tidak dapat & 122 & 13 & 8 & 0 & 143 & 0,12 \\
\hline Tidak diganti & 12 & 0 & 1 & 0 & 13 & \\
\hline Ganti tiap pemberian & 69 & 18 & 3 & 1 & 91 & \\
\hline Total & 203 & 31 & 12 & 1 & 247 & \\
\hline
\end{tabular}


Tabel 2: Distribusi Frekuensi Berdasarkan Kejadian Phlebitis Pasien yang Terpasang Infus

\begin{tabular}{c|c|c}
\hline Skala Phlebitis & Jumlah & Persentase (\%) \\
\hline Skala 0 & 203 & 82,2 \\
Skala 1 & 31 & 12,6 \\
Skala 2 & 12 & 4,8 \\
Skala 3 & 1 & 0,4 \\
Jumlah & 247 & 100 \\
\hline
\end{tabular}

Analisis multivariate dalam penelitian ini menggunakan uji regresi logistik ordinal. Hasil analisis multivariate pada Uji Pseudo $R$-Square berdasarkan nilai Cox and Snell didapatkan sebesar 0,245 yang secara statistik berarti variabel independen memberikan kontribusi terhadap kejadian phlebitis sebesar $24,5 \%$ dan sisanya $75,5 \%$ dijelaskan oleh variabel di luar model atau variabel yang tidak diteliti. Pada Uji parameter estemates menunjukkan besarnya pengaruh setiap variabel independen secara parsial terhadap kejadian phlebitis. Besarnya pengaruh setiap variabel independen yang memberikan pengaruh paling besar terhadap kejadian phlebitis bahwa jenis kelamin, pemberian terapi iv bolus dan penggantian tusukan infus memberi pengaruh signifikan terhadap kejadian phlebitis, sedangkan variabel lain tidak signifikan memberi pengaruh terhadap kejadian phlebitis secara bersama-sama. Pada uji Probabilitas OF Event melihat besarnya peluang dan kecenderungan kejadian phlebitis antara varian penggantian tusukan iv secara rutin dengan sesuai indikasi dan penggantian set drip secara rutin dengan tidak rutin setiap pemberian terapi didapatkan bahwa responden yang tidak diganti tusukan infus secara rutin berisiko phelebitis sebesar $100 \%$ dan juga responden yang tidak diganti set infus drip secara rutin berisiko phelebitis sebesar $100 \%$.

\section{DISKUSI}

\section{Kejadian Phlebitis}

Phlebitis skala 1 ditandai hanya satu dari tiga gejala, dan belum didiagnosis terjadi phlebitis serta tidak direkomendasikan dilakukan pelepasan infus dan tindakan observasi saja. Diagnosis phlebitis pada penelitian ini yaitu skala 2 dan 3 sebanyak 13 responden (5,3\%). Angka ini lebih tinggi dari standar yang ditetapkan Kementerian Kesehatan RI (Kemenkes RI, 2011) yaitu sebesar $1,5 \%$ dan $5 \%$ menurut standar INS (2011).

Penelitian ini sejalan dengan studi oleh Cicolini et al. (2014) terhadap 1.498 responden dari $5 \mathrm{RS}$ di Italia didapatkan kejadian phlebitis sebanyak $15,4 \%$ dan mayoritas $(94,4 \%)$ adalah phlebitis grade satu. Beberapa penelitian yang menunjukkan angka kejadian phlebitis melebihi standar INS yaitu penelitian Osei-Tutu et al. (2015) di suatu RS di Afrika, dengan angka kejadian phlebitis 52,2\% dari 224 sampel dengan VIP score. Studi oleh Pasalioglu \& Kaya (2014) terhadap 439 pasien, kejadian phlebitis $59,7 \%$. Angka kejadian phlebitis dari ketiga peneliti tersebut jauh lebih tinggi dari pada yang dilakukan peneliti. Demikian juga sejalan dengan penelitian dari Triyanto \& Upoyo (2006) terhadap 72 sampel, kejadian phlebitis sebanyak $17(22,9 \%)$. 
Tingginya kejadian phlebitis dari beberapa penelitian disebabkan faktor risiko phelebitis tidak berdiri sendiri, faktor internal dan eksternal pasien dapat menjadi risiko kejadian phlebitis (INS, 2016). Dapat disimpulkan phlebitis dapat dipengaruhi oleh berbagai faktor risiko. Kejadian phlebitis menjadi indikator mutu pelayanan rumah sakit (Kemenkes, 2011), sehingga perawat dituntut selalu memantau kejadian phlebitis pada pasien yang terpasang infus, akan tetapi berdasarkan pengamatan peneliti di RS Carolus pemantauan sudah dilakukan namun belum optimal dalam pelaporan kejadian phlebitis. Pasien dengan gejala nyeri dan bengkak pada lokasi tusukan belum dianggap terjadi phlebitis, yang dicatat phlebitis adalah bila terjadi kemerahan pada vena dan lokasi penusukan dan tidak dibuatkan skala phelebitis.

\section{Hubungan Penggantian Tusukan Infus dan Penggantian Set Drip dengan Kejadian Phlebitis}

Hasil penelitian ini menunjukkan bahwa penggantian tusukan mayoritas dilakukan pada hari ketiga perawatan yaitu sebanyak $28(35,9 \%)$ dan ada 8 phelebitis terjadi pada penggantian hari ketiga. Hasil analisis didapatkan ada pengaruh hari penggantian dengan kejadian phlebitis. Studi yang dilakukan oleh Li, Liu, \& Qin (2016) di satu rumah sakit di Cina terhadap perawat berpendapat bahwa penggantian rutin kateter diduga mengurangi risiko phlebitis dan infeksi darah, karena CDC merekomendasikan penggantian kateter iv tidak lebih sering dari 72-96 jam dan kebanyakan RS di China mengikuti rekomendasi tersebut. Pada penelitian tersebut hampir semua perawat percaya bahwa kateter harus diganti tidak lebih sering dari 71-96 jam dan kateter iv diganti setiap 72 jam untuk mencegah phlebitis.
Bolton (2015) melakukan penelitian terhadap 362 pasien yang dilakukan pemasangan infus, 185 sampel dilakukan penggantian tusukan infus bila ada kriteria dan 177 pasien dilakukan penggantian tusukan infus tiap 3 hari. Dilakukan penilaian komplikasi phlebitis, infiltrasi, sumbatan, terlepas, infeksi lokal dan infeksi darah akibat pemasangan kateter iv. Hasil penelitian didapatkan komplikasi pemasangan iv $68 / 1000$ hari (kelompok indikasi klinik) dan $66 / 1000$ hari (kelompok penggantian rutin $(p=0,86 ; \mathrm{HR} 1,03 ; 95 \% \mathrm{Cl}, 0,74-1,43)$. Tidak ada infeksi lokal atau infeksi darah terkait penusukan kateter iv pada kedua kelompok. Peneliti menyimpulkan penggantian tusukan infus pada indikasi klinis dilakukan pada satu dari dua pasien dan membutuhkan cukup satu saja kateter kanul dalam terapi iv, sebaliknya satu dari lima pasien menggunakan satu kateter kanul pada penggantian rutin. Peneliti menyimpulkan penggantian berdasarkan indikasi klinik dapat menghemat peralatan, waktu, staf dan ketidaknyamanan pasien. Kateter kanul merupakan benda asing yang terbuat dari polytetrafluoroethylene (Teflon), dimana tubuh dapat bereaksi dengan adanya benda tersebut. Semakin lama kateter iv kontak dengan pembuluh darah makan tubuh akan berisiko merusak lumen intima pembuluh darah yang berpotensi terjadi phlebitis (INS, 2011).

\section{Hubungan antara Pemberian Terapi Drip dengan Kejadian Phlebitis}

Dari hasil penelitian ini didapatkan dari 247 responden yang terpasang infus, 104 mendapat terapi drip, 6 responden mengalami phelebitis. Hasil analisis didapatkan tidak ada pengaruh yang bermakna pemberian terapi drip dengan kejadian phlebitis dengan $p=0,08$. Pada penelitian ini 104 pasien yang mendapat terapi drip, 91 pasien dilakukan 
dengan mengganti set infus setiap pemberian sehingga risiko phlebitis dapat dicegah.

Department of Health, Queensland Goverment (2015) menyatakan pemberian cairan dan obat melalui infus harus selalu dipertimbangkan karena dapat merusak pembuluh darah karena adanya perbedaan $\mathrm{pH}$ dan sifat kimia dari obat seperti kalium klorida, vancomycin dapat mengiritasi vena. Bila memasukkan terapi pada jalur infus iv perifer pastikan teknik asepsis dan tepat. Perawat dalam melakukan intervensi diharapkan tetap mempertahankan kepatenan aliran infus, mencegah pencampuran obat yang tidak kompatibel dengan cairan infus dengan cara melakukan pembilasan dengan menggunakan cairan NaCL $0.9 \%$ dengan cara disuntikkan atau infus dosis tunggal. Bila tidak ada aliran infus pembilasan sebanyak $5 \mathrm{cc}$ dan bila terpasang infus sebanyak $30 \mathrm{cc}$.

\section{Hubungan antara Penggantian Set Drip dengan Kejadian Phlebitis}

Hasil penelitian ini menunjukkan bahwa dari 247 responden yang terpasang infus, terdapat 105 (42,5\%) mendapat terapi infus dalam bentuk drip dan mayoritas pasien diganti set infus setiap pemberian terapi drip $(86,6 \%)$. Dalam hal ini phlebitis mayoritas terjadi pada pasien yang tidak mendapat terapi infus drip. Hasil analisis statistik menunjukkan tidak ada pengaruh bermakna penggantian set infus drip dengan phelebitis $(p=0,12)$. Secara teoritis pada pasien yang mendapat terapi intravena secara drip bila set infus diganti setiap pemberian terapi sangat berpotensi terjadi kontaminasi pada saat hub dilepaskan. Bila set infus dilepaskan dari kateter iv maka set harus dibuang dan diganti baru dan dipasang dengan tehnik aseptik dan memperhatikan standar pencegahan (O'Grady et al., 2011). Kateter perifer harus dilepas/diganti tidak lebih sering dari 72 jam atau bila ada tanda phlebitis score 2 (CDHB, 2015). Set infus yang digunakan dalam pemberian terapi dalam bentuk drip direkomendasikan diganti setiap pemberian dengan tehnik aseptik. Cairan infus yang diberikan secara drip memiliki tingkat osmolaritas yang lebih tinggi dari pada plasma, sehingga cairan tersebut berisiko menimbulkan iritasi pada pembuluh darah. Apabila set drip tidak diganti, ada kemungkinan sebagian kecil volume masih ada di selang infus dan apabila pemberian terapi selanjutnya diberikan, maka akan masuk ke pembuluh darah yang berisiko tinggi mengiritasi (Loveday et al., 2014).

\section{Anaisis Pengaruh Penggantian Rutin Penusukan Kateter Intravena Perifer dan Set Infus Terapi Drip Terhadap Terjadinya Phlebitis}

Hasil penelitian pada uji probabilitas secara statistik didapatkan bahwa responden yang tidak diganti tusukan infus secara rutin dan tidak diganti set drip secara rutin berisiko phlebitis sebesar $100 \%$. Sebanyak 164 responden yang tidak ada pengantian tusukan kateter iv hanya 5 responden yang mengalami phlebitis yaitu pada skala 1 sebanyak 4 responden $(2,43 \%)$. Mayoritas penggantian tusukan infus dilakukan dengan alasan karena phlebitis yaitu sebanyak 35 responden dan kejadian phlebitis mayoritas pada skala satu dan penggantian tusukan dilakukan walaupun phlebitis skala satu karena aliran infus tidak lancar. Penggantian infus dengan alasan reposisi dilakukan pada 23 responden dan phlebitis hanya terjadi pada satu responden yaitu pada skala satu.

Penelitian ini sejalan dengan penelitian yang dilakukan oleh Salgueiro-Oliveira, Parreira \& Veiga (2012) terhadap 1.244 responden kejadian phlebitis sebesar $11.9 \%$. hasil analisis multivariate didapatkan pemberian infus $\mathrm{KCl}$ berpeluang OR: 2.112, pemberian antibiotika OR 1.877 terjadi 
phlebitis. Penelitian Siti (2015) diperoleh faktor yang paling dominan berhubungan dengan terjadinya phlebitis adalah tehnik desinfeksi $(\mathrm{OR}=4,567)$. Pada penelitian yang dilakukan oleh Osei-Tutu et al. (2015), penggunaan kateter iv lebih dari 4 hari berisiko empat kali lebih tinggi berisiko phlebitis. Penempatan kateter IV di pembuluh darah adalah benda asing bagi tubuh dan akses masukkan kateter berpotensi masuknya bakteri yang ada di kulit ke pembuluh darah. Lamanya kateter kontak dengan pembuluh darah berpotensi merubah struktur intima pembuluh darah yang berisiko tinggi terjadi phlebitis, untuk itu tindakan penggantian rutin setiap 3 hari tusukan infus dapat mencegah terjadinya phlebitis.

\section{SIMPULAN}

Pemberian terapi iv adalah untuk menggantikan, mengkoreksi kekurangan cairan, dan tranfusi darah, tetapi pasien berisiko mengalami phlebitis. Hasil penelitian ini didapatkan secara statistik ada pengaruh pemberian terapi iv bolus $(p=0,03)$, lama pemasangan kateter iv $(p=0,00)$ terhadap terjadinya phlebitis. Hasil analisis uji probabilitas yaitu penggantian rutin kateter intravena dan set infus didapatkan risiko phlebitis sebesar $100 \%$ bila tidak dilakukan penggantian secara rutin. Penelitian ini merekomendasikan semua pasien dewasa yang mendapat terapi cairan infus harus dilakukan penggantian tusukan secara rutin setiap tiga hari atau sebelum tiga hari bila sudah ada tanda phlebitis dan penggantian set infus drip setiap pemberian terapi. Apabila tidak memungkinkan penggantian setiap pemberian, peneliti merekomendasikan pembilasan dengan cairan isotonik setelah pemberian terapi drip. Penelitian lebih lanjut yaitu meneliti faktor risiko lain di luar model yang telah diteliti, seperti ketrampilan perawat dalam melakukan insersi, cairan yang digunakan untuk desinfektan dan melibatkan pasien dalam perawatan.

\section{DAFTAR PUSTAKA}

Bolton, D. (2015) Clinically indicated replacement of peripheral cannulas. British Journal of Nursing, Therapy Supplement, 24: S4-S1.

Bonnici, E. T. (2012). Safe patient care through better peripheral intravenous catheter management. Int J Infect Control, 8(2).

Çakar, V. (2008). Infection control practices at peripheral venous catheters and intravasculer catheters. J Nurs Educ Res, 5(1):24-33.

Centerbury District Health Board (CDHB). (2015). Peripheral intravenous therapy. Retrieved from http://www. cdhb.health.nz/Hospitals-Services/ Health-Professionals/CDHB-Policies/ Fluid-Medication-Manual/Documents/ Peripheral-IV\%20therapy-Policy.pdf

Cicolini, G., Manzoli, L., Simonetti, V., Flacco, M. E., Comparcini, D., Capasso, L., Di Baldassarre, A. (2014). Phlebitis risk varies by peripheral venous catheter site and increases after 96 hours: a large multi-centre prospective study. $J A d v$ Nurs, 70(11): 2539-2549.

Department of Health, Queensland Goverment. (2015). Guideline Peripheral intravenous catheter (PIVC). Retrieved from https://www.health.qld.gov.au/ data/assets/pdf_file/0025/444490/icarepivc-guideline.pdf

Infusion Nurses Society (INS). (2011) Infusion nursing standards of practice. Journal of Infusion Nursing, 29(1S): SI-90

(2016). Infusion therapy standards of practice. Journal of Infusion Nursing, 39(1S): S1-S159.

Jackson A. (1998) Infection control: A battle in vein infusion phlebitis. Nursing Times, 94(4): 67-71. 
Kementerian Kesehatan RI. (2011). Peraturan Menteri Kesehatan Nomor 1691 Tahun 2011 tentang keselamatan pasien di rumah sakit. Jakarta: Kementerian Kesehatan Republik Indonesia.

Li, X. F., Liu, W., \& Qin, Y. (2016). Nurses' perception of risk factors for infusion phlebitis: A cross-sectional survey. Chinese Nursing Research, 3(1), 37-40. Loveday, H. P., Wilson, J. A., Pratt, R. J., Golsorkhi, M., Tingle, A., Bak, A., Browne, J., Prieto, J. and Wilcox M. (2014). Epic3: National evidence-based guidelines for preventing healthcare associated infections in NHS hospitals in England. Journal of Hospital Infection, 86(Supp.1): S1-S70.

O'grady, N. P., Alexander, M., Burns, L. A., Dellinger, E. P., Garland, J., Heard, S. O. \& Raad, I. I. (2011). Guidelines for the prevention of intravascular catheterrelated infections. Clinical infectious diseases, 52(9): e162-e193.

Osei-Tutu, E., Tuoyire, D. A., Debrah, S., Ayetey, H. (2015). Peripheral intravenous cannulation and phlebitis risk at Cape Teaching Hospital. Postgraduate Medical Journal of Ghana, 4(1)

Pasalioglu, K.B. \& Kaya, H. (2014). Catheter indwell time and phlebitis development during peripheral intravenous catheter administration Pak J Med Sci, 30(4): 725-730.

Ray-Barruel, G., Polit, D. F., Murfield, J.E., \& Rickard C. M.. (2014). Infusion phlebitis assessment measures: A systematic review.. Journal of Evaluation in Clinical Practice, 20(2): 191-202.

Royal College of Nursing (RCN). (2010). Standards for infusion therapy. London: Royal College of Nursing. (2016). Infusion therapy standards: Rapid evidence review. London: Royal College of Nursing.
Salgueiro-Oliveira, A., Parreira, P., \& Veiga, P. (2012). Incidence of phlebitis in patients with peripheral intravenous catheters: The influence of some risk Factors. Australian Journal of Advanced Nursing, 30(2): 32

Stuart, R. L., Cameron, D. R., Scott, C. (2013). Peripheral intravenous catheterassociated staphylococcus aureus bacteraemia: more than 5 years of prospective data from two tertiary health services. Medical Journal of Australia, 198(10): 551- 553.

Siti, R. (2015). Analisis faktor risiko terjadinya phlebitis di RSUD Puri Husada Tembilahan (tesis). Universitas Andalas, Padang, Indonesia.

Triyanto, E., \& Upoyo, A. S. (2006). Analisis Faktor-Faktor Yang Berpengaruh Terhadap Kejadian Plebitis di RSUD Purbalingga. Jurnal Keperawatan Soedirman, 1(1), 43-52.

Uzun, S. (2012). Intravenous fluid therapy, In: Fundamentals of nursing, nursing science and art. Asti AT, Karadağ A. (Ed.). Istanbul: Akademi Press and Publishing.

Wallis, M. C., McGrail, M., Webster, J., Marsh, N., Gowardman, J., Playford, E. G. R. \& Rickard, C. M. (2014). Risk factors for peripheral intravenous catheter failure: A multivariate analysis of data from a randomized controlled trial. Infection Control and Hospital Epidemiology, 35(1): 63-68.

Webster, J., Osborne, S., Rickard, C., New, K. (2015). Replacing a peripheral venous catheter when clinically indicated versus routine replacement.. Retrieved from http://www.cochrane.org/CD007798/ PVD_replacing-peripheral-venouscatheter-when-clinically-indicatedversus-routine-replacement 